\title{
Morphological and molecular characterization of Cladosporium cladosporioides species complex causing pecan tree leaf spot
}

C. Walker ${ }^{1}$, M.F.B. Muniz' ${ }^{1}$ J.M. Rolim ${ }^{1}$, R.R.O. Martins ${ }^{1}$, V.C. Rosenthal ${ }^{1}$, C.G. Maciel $^{1}$, R. Mezzomo ${ }^{1}$ and L.R.S. Reiniger ${ }^{2}$

${ }^{1}$ Departamento de Defesa Fitossanitária, Universidade Federal de Santa Maria, Santa Maria, RS, Brasil

${ }^{2}$ Departamento de Fitotecnia, Universidade Federal de Santa Maria, Santa Maria, RS, Brasil

Corresponding author: C. Walker

E-mail: clairwalker@gmail.com

Genet. Mol. Res. 15 (3): gmr.15038714

Received April 18, 2016

Accepted June 7, 2016

Published September 16, 2016

DOI http://dx.doi.org/10.4238/gmr.15038714

Copyright $(2016$ The Authors. This is an open-access article distributed under the terms of the Creative Commons Attribution ShareAlike (CC BY-SA) 4.0 License

\begin{abstract}
The objective of this study was to characterize species of the Cladosporium cladosporioides complex isolated from pecan trees (Carya illinoinensis) with symptoms of leaf spot, based on morphological and molecular approaches. Morphological attributes were assessed using monosporic cultures on potato dextrose agar medium, which were examined for mycelial growth, sporulation, color, and conidia and ramoconidia size. Molecular characterization comprised isolation of DNA and subsequent amplification of the translation elongation factor $1 \alpha(T E F-1 \alpha)$ region. Three species of the C. cladosporioides complex were identified: C. cladosporioides, Cladosporium pseudocladosporioides, and Cladosporium subuliforme. Sporulation was the most important characteristic differentiating
\end{abstract}


species of this genus. However, morphological features must be considered together with molecular analysis, as certain characters are indistinguishable between species. $T E F-1 \alpha$ can be effectively used to identify and group isolates belonging to the $C$. cladosporioides complex. The present study provides an important example of a methodology to ascertain similarity between isolates of this complex causing leaf spot in pecan trees, which should facilitate future pathogenicity studies.

Key words: Carya illinoinensis; TEF-1 $\alpha$; Phylogeny; Scab; Leaf spot

\section{INTRODUCTION}

The pecan tree Carya illinoinensis (Wangenh.) K. Koch belongs to the Juglandaceae family, and is considered the most important species of its genus, members of which grow naturally throughout North America. Its fruits are harvested from native trees across its natural range; however, pecan farming extends considerably beyond this area, from Ontario, Canada, to south Oaxaca, Mexico, and from the Atlantic coast of Virginia and western Carolina to California. In addition, the pecan tree is commercially grown in smaller areas of Israel, South Africa, Australia, Egypt, Peru, Argentina, and Brazil (Thompson and Conner, 2012). In Brazil, almost all of the genetic material present in C. illinoinensis cultivars used in commercial orchards originates from the United States. According to Ministério da Agricultura, Pecuária e Abastecimento (2015), of the 41 cultivars registered by three companies located in Rio Grande do Sul State, only two were developed in-country. The number of areas containing pecan plantations has increased, mainly in the states of Rio Grande do Sul, Santa Catarina, and Paraná (Instituto Brasileiro de Geografia e Estatística, 2015).

The Juglandaceae are monoecious plants, with axillary androecious flowers and gynoecious flowers in erect terminal spikes. The drupaceous fruits have a husk that opens when ripe. The genera Carya and Juglans both produce edible nuts and valuable timber, and are considered the best-known genera in southern Brazil. C. illinoinensis is a large tree $(50 \mathrm{~m})$ with a straight trunk ( $150 \mathrm{~cm}$ in diameter), elliptical canopy, and deciduous foliage comprising alternate odd-pinnate leaves, each with 9-17 leaflets (Marchiori, 1997).

In Brazil, few studies have reported the occurrence of diseases in pecan trees. However, pathogens have recently been identified in pecan cultures, including Fusarium spp causing choke disease and leaf necrosis associated with root rot (Lazarotto et al., 2014a), and Pestalotiopsis spp responsible for leaf spot (Lazarotto et al., 2014b).

Scab caused by Fusicladium effusum G. Winter (syn. Cladosporium caryigenum) is regarded as the most important pecan disease in the southeastern United States and other humid regions of eastern South Africa, southern Brazil, and northeastern Mexico where the species is cultivated (Beck et al., 2005). Although some authors identify F. effusum as the source of pecan scab in Brazil, no studies have provided genetic evidence of the existence of this pathogen in the environment. However, our research group (Walker et al., 2016) has described the "First report of species in the Cladosporium cladosporioides complex causing pecan leaf spot in Brazil", namely C. cladosporioides, Cladosporium pseudocladosporioides, and Cladosporium subuliforme.

Cladosporium spp have a wide ecological distribution, occurring in all substrate types and in a wide variety of hosts, surviving in a biotrophic or necrotrophic manner, or even

Genetics and Molecular Research 15 (3): gmr.15038714 
in senescent plant tissue. Furthermore, Cladosporium herbarum, C. cladosporioides, and Cladosporium oxysporum do not seem to have obvious environmental preferences (Bensch et al., 2012).

C. cladosporioides is the most common saprophytic species of the genus, and is widely distributed around the world. It survives on senescent plant material or in fresh leaves as a secondary invader, but can also be isolated from air, soil, textiles, and numerous other substrates and is considered an endophytic fungus (Bensch et al., 2012). Despite being thought of as saprophytic, however, C. cladosporioides has been implicated in diseases such as leaf spot and scab. In 1973, Anilkumar and Seshadri (1975) identified this fungus as the causative agent of leaf spot in sunflowers (Helianthus annuиs L.) in Bangalore, India. In addition, Chen et al. (2009) were the first to report the occurrence of scab caused by C. cladosporioides in papaya (Carica papaya) in Taiwan.

Leaf spot caused by species of the genus Cladosporium has been observed in several plants species. In Greece, Berner et al. (2007) described the presence of C. herbarum in Centaurea solstitialis L., causing light-brown leaf spots on the lower leaves and necrotic lesions along the stem. Moreover, in Syagrus oleracea, Oliveira et al. (2014) verified the existence of Cladosporium perangustum-derived leaf spot. According to these authors, the first symptoms appear as small, yellowish, water-soaked spots on young or mature leaves, which develop into brown necrotic streaks running parallel to the leaf veins. In China, Zheng et al. (2014) reported leaf spot caused by C. oxysporum in a greenhouse culture of Solanum melongena L.

Considering the aforementioned findings, the objective of this study was to characterize species of the $C$. cladosporioides complex responsible for leaf spot in the pecan tree, using both morphological and molecular characteristics.

\section{MATERIAL AND METHODS}

Collection of plant material from pecan orchards showing symptoms of disease caused by Cladosporium spp was carried out from January to April 2014, in the southern Brazilian states of Rio Grande do Sul (RS), Santa Catarina (SC), and Paraná (PR). Collection points were georeferenced with the Global Positioning System, as shown in Table 1.

Table 1. Areas in Rio Grande do Sul (RS), Santa Catarina (SC), and Paraná (PR) states in which Cladosporium spp isolates were collected from pecan tree (Carya illinoinensis) orchards.

\begin{tabular}{|c|c|c|c|c|}
\hline Area code & Isolates $(\mathrm{N})$ & Collection date & County/state & DMS coordinates \\
\hline $1 \mathrm{PR}$ & 1 & January 2014 & Missal/PR & $-25^{\circ} 04^{\prime} 50^{\prime \prime} \mathrm{S},-54^{\circ} 16^{\prime} 03^{\prime \prime} \mathrm{W}$ \\
\hline $2 \mathrm{PR}$ & 2 & January 2014 & Toledo/PR & $-24^{\circ} 75^{\prime} 24^{\prime \prime S},-53^{\circ} 66^{\prime} 45^{\prime \prime} \mathrm{W}$ \\
\hline $3 \mathrm{PR}$ & 1 & January 2014 & Assis Chateaubriand/PR & $-24^{\circ} 41^{\prime} 00^{\prime \prime} \mathrm{S},-53^{\circ} 52^{\prime} 13^{\prime \prime} \mathrm{W}$ \\
\hline 4PR & 1 & January 2014 & Pato Branco/PR & $-26^{\circ} 27^{\prime} 37^{\prime \prime} \mathrm{S},-52^{\circ} 60^{\prime} 34^{\prime \prime} \mathrm{W}$ \\
\hline $12 \mathrm{PR}$ & 8 & March 2014 & Porto Amazonas/PR & $-25^{\circ} 32^{\prime} 22^{\prime \prime} \mathrm{S},-49^{\circ} 54^{\prime} 29^{\prime \prime} \mathrm{W}$ \\
\hline $6 \mathrm{SC}$ & 1 & January 2014 & Palmitos/SC & $-27^{\circ} 12^{\prime} 00^{\prime \prime} \mathrm{S},-53^{\circ} 22^{\prime} 10^{\prime \prime} \mathrm{W}$ \\
\hline $7 \mathrm{SC}$ & 1 & January 2014 & São João do Oeste/SC & $-27^{\circ} 05^{\prime} 01^{\prime \prime S},-53^{\circ} 58^{\prime} 37^{\prime \prime} \mathrm{W}$ \\
\hline $8 \mathrm{RS}$ & 1 & February 2014 & Alegrete/RS & $-29^{\circ} 48^{\prime} 53^{\prime \prime S},-55^{\circ} 49^{\prime} 15^{\prime \prime} \mathrm{W}$ \\
\hline 9RS & 1 & February 2014 & Uruguaiana/RS & $-29^{\circ} 26^{\prime} 11^{\prime \prime S},-56^{\circ} 41^{\prime} 05^{\prime \prime} \mathrm{W}$ \\
\hline 10RS & 1 & February 2014 & Itaqui/RS & $-29^{\circ} 12^{\prime} 07^{\prime \prime} \mathrm{S},-56^{\circ} 29^{\prime} 34^{\prime \prime} \mathrm{W}$ \\
\hline 11RS & 1 & February 2014 & São Borja/RS & $-28^{\circ} 63^{\prime} 39^{\prime \prime} \mathrm{S},-55^{\circ} 84^{\prime} 83^{\prime \prime} \mathrm{W}$ \\
\hline 13RS & 4 & March 2014 & Santa Maria (Pains)/RS & $-29^{\circ} 45^{\prime} 25^{\prime \prime} \mathrm{S},-53^{\circ} 40^{\prime} 00^{\prime \prime} \mathrm{W}$ \\
\hline 14RS & 8 & March 2014 & Santa Maria (Fepagro)/RS & $-29^{\circ} 40^{\prime} 19^{\prime \prime} \mathrm{S},-53^{\circ} 54^{\prime} 35^{\prime \prime} \mathrm{W}$ \\
\hline $15 \mathrm{RS}$ & 3 & April 2014 & Dilermando de Aguiar/RS & $-29^{\circ} 47^{\prime} 52^{\prime \prime} \mathrm{S},-54^{\circ} 05^{\prime} 45^{\prime \prime} \mathrm{W}$ \\
\hline 16RS & 4 & April 2014 & Cachoeira do Sul/RS & $-30^{\circ} 00^{\prime} 20^{\prime \prime} \mathrm{S},-52^{\circ} 53^{\prime} 00^{\prime \prime} \mathrm{W}$ \\
\hline 17RS & 2 & April 2014 & Cachoeira do Sul/RS & $-30^{\circ} 00^{\prime} 16^{\prime \prime} \mathrm{S},-52^{\circ} 53^{\prime} 25^{\prime \prime} \mathrm{W}$ \\
\hline
\end{tabular}

Genetics and Molecular Research 15 (3): gmr.15038714 
Compound pecan leaves with typical symptoms of leaf spot caused by Cladosporium spp were collected from east side to west side in each tree, by removing two leaves from the lower and upper thirds of the crown, to get a total of eight leaves per tree.

For each area, 12 trees were sampled by the traversal walking method. Plant material collected in the field was properly identified, packed in aluminum foil and plastic bags, and placed in Styrofoam boxes containing ice to maintain a low temperature during transport to the laboratory. The material was subsequently transported to Laboratório de Fitopatologia "Elocy Minussi" of Departamento de Defesa Fitossanitária at Universidade Federal de Santa Maria, for identification and isolation of pathogens. Cladosporium spp were isolated from necrotic lesions on pecan leaflets. Small dark-brown-to-black spots were observed, as well as others of a whitish-gray color with a brown halo. As the disease progressed, some lesions were found to coalesce and form cracks appearing alongside the veins (Figure 1).

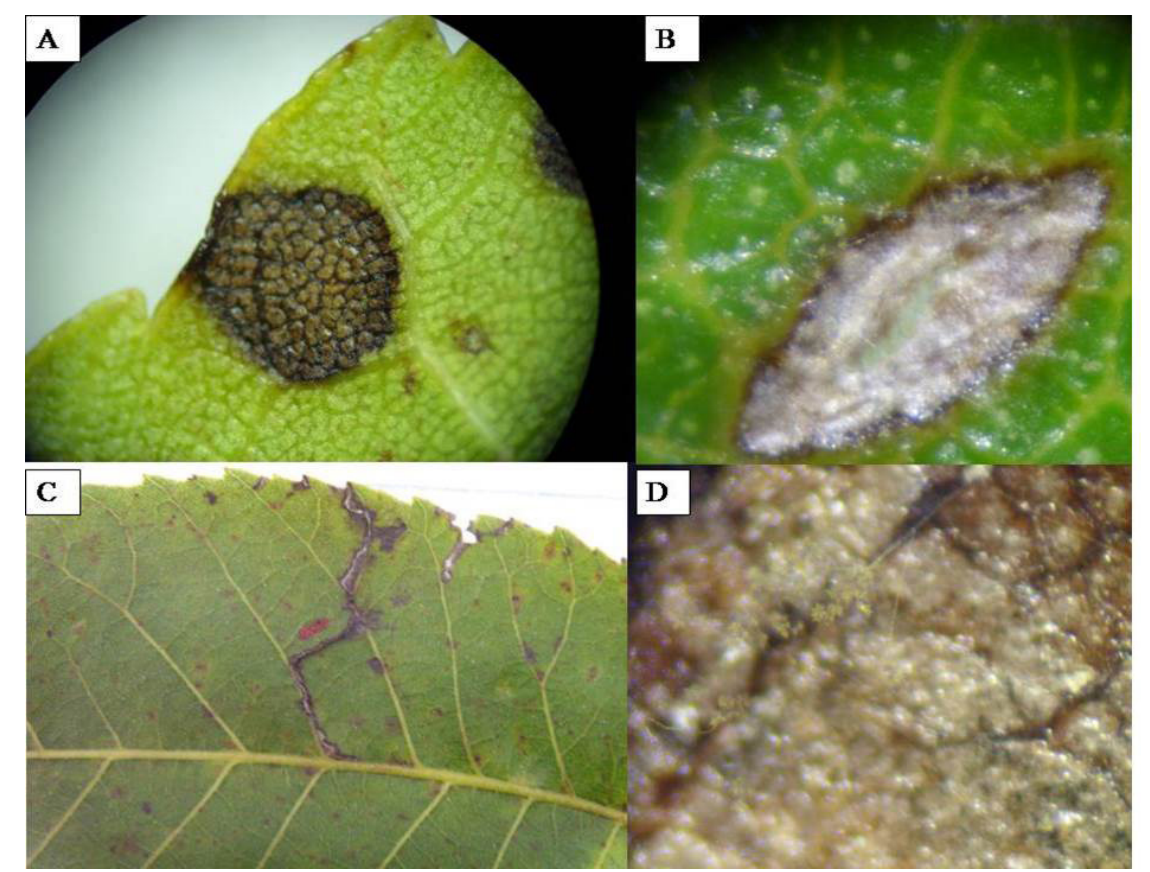

Figure 1. Leaf spot symptoms caused by Cladosporium spp in pecan trees (Carya illinoinensis). A. and B. Appearance of lesions under a stereoscopic microscope. C. Necrotic lesions were observed to coalesce and break the leaf blade along the veins. D. Stereoscopic microscope view of necrotic lesions with presence of fungal reproductive structures.

For pathogen isolation, leaflets showing disease symptoms were first sterilized for $30 \mathrm{~s}$ with $70 \%$ ethanol and $1 \%$ sodium hypochlorite, and rinsed twice in autoclaved distilled water. The plant material was then placed on sheets of filter paper to remove excess liquid, and transferred to sterilized plastic gerbox containers (transparent polystyrene crystal; $11 \mathrm{x}$ $11 \times 3.5 \mathrm{~cm}$ ) containing two sheets of pre-moistened filter paper. The boxes were kept in a moist chamber at $25^{\circ} \mathrm{C}$ under a 12-h photoperiod for 7 days. After this time, a stereoscopic microscope was used to observe lesions for pathogenic signs and to isolate the organism responsible. 
After pathogen isolation, the monosporic culture technique was employed to purify isolates, involving the transfer of a single conidium to potato dextrose agar (PDA) medium, as described by Fernandez (1993). Subsequently, the plates were transferred to a $24^{\circ} \mathrm{C}$ incubation chamber and subjected to a 12-h photoperiod for 2 weeks, before being stored according to the Castellani method (Alfenas and Ferreira, 2007), and by spore suspension in silica gels kept in a freezer in the dark, as suggested by Clive H. Bock (personal communication, July 16, 2014).

All 40 isolates obtained were used for morphological characterization. The experiment was performed using fungal mycelial disks approximately $6 \mathrm{~mm}$ in diameter, obtained from colonies after 2 weeks of growth on PDA medium. The disks were transferred to Petri dishes containing PDA medium, and kept in a $24^{\circ} \mathrm{C}$ incubation chamber under a 12 -h photoperiod for 19 days. Four replicates were made for each isolate, each replicate consisting of one plate. Mycelial growth was evaluated daily by measuring the average colony diameter in two diametrically opposite directions. To measure the concentration of spore suspensions, $20 \mathrm{~mL}$ autoclaved distilled water was added to each plate, and colonies were scraped with a Drigalski spatula before being filtered through a double layer of gauze. Spore concentration (conidia/mL) was estimated with a Neubauer chamber, and evaluation of sporulation was performed after 20 days. Plates cultured for 19 days were used for colony color estimation, and observations of both the top and reverse sides were made according to the Munsell Soil Color Chart (Munsell Color, Grand Rapids, MI, USA). To assess conidia and ramoconidia size, slides were prepared and measurements performed by optical microscopy at $40 \mathrm{X}$ magnification, with a ruler attached to the eyepiece lens. The width and length of 50 conidia and 15 ramoconidia were recorded for each isolate.

Morphological characteristics were determined according to the methodology and $C$. cladosporioides species complex classification key proposed by Bensch et al. (2010). Isolates were transferred to synthetischer nährstoffarmer agar medium and incubated at $24^{\circ} \mathrm{C}$ under a 12-h photoperiod for 7 to 9 days (Bensch et al., 2010), after which, fungal structures were observed with an optical microscope.

DNA was extracted from the mycelium produced by each of the 39 isolates in potato dextrose broth, utilizing the cetyltrimethylammonium bromide method described by Doyle and Doyle (1990). The genomic DNA obtained was used in a polymerase chain reaction (PCR) to amplify the translation elongation factor $1 \alpha(T E F-1 \alpha)$ genic sequence using the primers EF-F (5'-GTYGTYATYGGYCACGTYGAYTC-3'; de Souza et al., 2012) and Tef997R (5'-CAGTACCGGCRGCRATRATSAG-3'; Shoukouhi and Bissett, 2009).

Each reaction included approximately $30 \mathrm{ng}$ DNA, 10X buffer (Life Technologies), $2.5 \mu \mathrm{M}$ each deoxynucleotide, $20 \mathrm{nM} \mathrm{MgCl}_{2}, 25$ pmol each primer, $5 \mathrm{U}$ Taq polymerase, and ultrapure water (autoclaved MiliQ water) up to the required volume. Amplification was performed on a PTC-100 thermocycler (MJ Research Inc., Waltham, MA, USA) under the following cycling conditions: $94^{\circ} \mathrm{C}$ for $2 \mathrm{~min}, 30$ cycles of $94^{\circ} \mathrm{C}$ for $45 \mathrm{~s}, 55^{\circ} \mathrm{C}$ for $30 \mathrm{~s}$, and $72^{\circ} \mathrm{C}$ for $35 \mathrm{~s}$, then $72^{\circ} \mathrm{C}$ for $10 \mathrm{~min}$. PCR products were subsequently stored at $4^{\circ} \mathrm{C}$. A negative control lacking the DNA template was run alongside the reactions. Amplified DNA fragments and the negative control were subjected to agarose gel electrophoresis on a $1.2 \%$ gel in $1 \mathrm{X}$ Tris/borate/ethylenediaminetetraacetic acid buffer containing ethidium bromide, and visualized under ultraviolet light.

PCR products were purified with $13 \%$ polyethylene glycol 8000 , and oligonucleotides EF-F and Tef997R were used in sequencing reactions carried out on a MegaBACE 500 system (Amersham Biosciences, Little Chalfont, UK). The sequenced fragments were then analyzed 
using BioEdit (Hall, 1999), and compared to those of species from the C. cladosporioides complex available on GenBank. For construction of a phylogenetic tree, the Basic Local Alignment Search Tool (BLAST; http://blast.ncbi.nlm.nih.gov) was first used to align the nucleotide sequences obtained from each isolate. GenBank sequences with the highest "scores" were then selected. The nucleotide sequences were aligned using the ClustalW algorithm and phylogenetic analysis was conducted based on the neighbor-joining method with 1000 replicates using MEGA version 4 (Tamura et al., 2007). Finally, similarity between isolate sequences was calculated using the BLAST procedure.

Quantitative data concerning morphological characteristics were subjected to multivariate cluster analysis using GENES software, version 2009.7.0. A standardized Euclidean distance matrix (D2) was calculated as a dissimilarity measure and used for cluster analysis employing the unweighted pair group method with arithmetic mean (UPGMA; Cruz, 2008).

\section{RESULTS}

The morphological characteristics of the Cladosporium spp isolates were consistent with those in published descriptions of species from the C. cladosporioides complex (Bensch et al., 2010). Mycelial growth varied between 63.3 (isolate 1PR) and $75.06 \mathrm{~mm}$ (16/16RS) after 19 days of incubation (Table 2). Colonies of C. pseudocladosporioides, a species included within the same complex, grow to $65-78 \mathrm{~mm}$ in diameter after 14 days on PDA medium, as described in the literature mentioned above. Only isolate 16/2RS exhibited abundant aerial mycelia, with others showing sparse and flat growth. On the surface, colonies were greenish grey to dark greenish grey, while the reverse of the plate revealed a greenish-black coloration (Table 2). Sporulation ranged from $2.09 \times 10^{6}(6 \mathrm{SC})$ to $68.63 \times 10^{6}$ spores $/ \mathrm{mL}$ (14/9RS). Conidia varied from 2.47 to $2.9 \mu \mathrm{m}$ in width, and 4.1 to $6.7 \mu \mathrm{m}$ in length (Table 2), differing in shape from ellipsoid to thin-walled limoniform, and forming long, branched, pale olivebrown chains, most without a septum. Ramoconidial widths between 2.67 and $4.67 \mu \mathrm{m}$, and lengths from 12.5 to $23.67 \mu \mathrm{m}$ were observed. Ramoconidia had thin walls, similar coloring to conidia, and one or no septa (Table 2).

Morphological characteristics (mycelial growth, sporulation, width and length of conidia and ramoconidia) of the Cladosporium spp isolates were grouped according to similarity, and the extent of their contribution to inter-isolate discrimination was established. Through multivariate analysis, the relative importance of each feature to isolate dissimilarity was estimated, with sporulation being responsible for the most significant contribution of $96.13 \%$, and mycelial growth accounting for only $2.37 \%$. Of the remaining characters, conidial length and width were associated with only 0.0024 and $0.0849 \%$ of variance, respectively, and width and length of ramoconidia 0.0741 and $1.3348 \%$, respectively (Figure 2).

From the UPGMA dendrogram, it was observed that the Cladosporium spp isolates formed five groups at a level of $30 \%$ dissimilarity. The group formed by isolates $6 \mathrm{SC}, 16 / 2 \mathrm{RS}$, 7SC, 16/16RS, 13/1RS, 2/1PR, and 10RS exhibited 100\% dissimilarity in relation to other clusters, indicating that these isolates are morphologically distinct from the other groupings generated. Of all isolates, $6 \mathrm{SC}$ and $16 / 2 \mathrm{RS}$ were found to be morphologically closest, showing only $3.42 \%$ dissimilarity. Moreover, the pairs formed by isolates $14 / 5 \mathrm{RS}$ and $16 / 17 \mathrm{RS}$, and $2 / 2 \mathrm{PR}$ and $8 \mathrm{RS}$ demonstrated minimal dissimilarity, with a value of $3.95 \%$ in each case (Figure 2).

Genetics and Molecular Research 15 (3): gmr.15038714 
Table 2. Morphological characteristics of Cladosporium spp isolates from pecan (Carya illinoinensis) leaves after a 19 -day incubation on potato dextrose agar (PDA) medium at $24^{\circ} \mathrm{C}$ under a 12 -h photoperiod.

\begin{tabular}{|c|c|c|c|c|c|c|c|c|}
\hline \multirow[t]{2}{*}{ Isolate } & \multirow[t]{2}{*}{$\begin{array}{l}\text { Colony diameter } \\
(\mathrm{mm})\end{array}$} & \multirow[t]{2}{*}{$\begin{array}{c}\text { Sporulation } \\
\left(\mathrm{x} 10^{6} \text { spores } / \mathrm{mL}\right)\end{array}$} & \multicolumn{2}{|c|}{ Conidia } & \multicolumn{2}{|c|}{ Ramoconidia } & \multicolumn{2}{|c|}{$\begin{array}{l}\text { Colony pigmentation on PDA (Munsell } \\
\text { Soil Color Chart) }\end{array}$} \\
\hline & & & Width $(\mu \mathrm{m})$ & Length $(\mu \mathrm{m})$ & Width $(\mu \mathrm{m})$ & Length $(\mu \mathrm{m})$ & Reverse & Surface \\
\hline $1 \mathrm{PR}$ & 63.30 & 41.47 & 2.75 & 5.50 & 3.17 & 13.50 & Greenish-black & Greenish-gray \\
\hline $2 / 1 \mathrm{PR}$ & 72.24 & 3.36 & 2.60 & 5.15 & 4.17 & 23.67 & Greenish-black & Greenish-gray \\
\hline $2 / 2 \mathrm{PR}$ & 69.52 & 26.27 & 2.50 & 5.30 & 3.00 & 13.67 & Greenish-black & Greenish-gray \\
\hline $3 \mathrm{PR}$ & 66.74 & 30.80 & 2.55 & 4.50 & 3.83 & 16.00 & Greenish-black & Greenish-gray \\
\hline 4PR & 72.87 & 13.93 & 2.65 & 5.85 & 3.83 & 15.17 & Greenish-black & Greenish-gray \\
\hline 12/1PR & 69.34 & 28.73 & 2.70 & 5.00 & 3.50 & 14.70 & Greenish-black & Greenish-gray \\
\hline $12 / 8 \mathrm{PR}$ & 71.60 & 58.93 & 2.65 & 4.95 & 4.17 & 15.33 & Greenish-black & Dark greenish-gray \\
\hline $12 / 7 \mathrm{PR}$ & 64.87 & 49.93 & 2.65 & 5.40 & 3.50 & 17.83 & Greenish-black & Greenish-gray \\
\hline 12/18PR & 67.47 & 25.43 & 2.60 & 4.90 & 3.17 & 16.33 & Greenish-black & Greenish-gray \\
\hline $12 / 9 \mathrm{PR}$ & 71.54 & 28.03 & 2.55 & 5.25 & 2.67 & 15.67 & Greenish-black & Greenish-gray \\
\hline $12 / 14 \mathrm{PR}$ & 70.04 & 41.07 & 2.80 & 5.20 & 4.17 & 16.33 & Greenish-black & Greenish-gray \\
\hline $12 / 3 \mathrm{PR}$ & 70.02 & 46.83 & 2.62 & 5.35 & 3.83 & 16.17 & Greenish-black & Dark greenish-gray \\
\hline $12 / 6 \mathrm{PR}$ & 67.82 & 56.50 & 2.77 & 5.30 & 4.17 & 17.33 & Greenish-black & Greenish-gray \\
\hline $6 \mathrm{SC}$ & 74.21 & 2.09 & 2.50 & 6.40 & 4.17 & 15.83 & Greenish-black & Greenish-gray \\
\hline $7 \mathrm{SC}$ & 73.00 & 6.84 & 2.70 & 6.05 & 3.00 & 15.67 & Greenish-black & Greenish-gray \\
\hline $8 \mathrm{RS}$ & 68.67 & 25.77 & 2.60 & 5.85 & 3.33 & 14.50 & Greenish-black & Greenish-gray \\
\hline 9RS & 68.70 & 39.63 & 2.60 & 4.85 & 3.17 & 13.50 & Greenish-black & Dark greenish-gray \\
\hline 10RS & 66.75 & 10.18 & 2.55 & 6.45 & 3.00 & 16.00 & Greenish-black & Greenish-gray \\
\hline $11 \mathrm{RS}$ & 68.17 & 38.67 & 2.55 & 5.75 & 2.83 & 22.50 & Greenish-black & Greenish-gray \\
\hline 13/10RS & 68.13 & 32.00 & 2.62 & 4.90 & 3.17 & 16.67 & Greenish-black & Greenish-gray \\
\hline 13/1RS & 68.39 & 2.97 & 2.47 & 6.70 & 3.33 & 14.17 & Greenish-black & Greenish-gray \\
\hline 13/12RS & 69.37 & 24.33 & 2.57 & 5.40 & 4.50 & 13.83 & Greenish-black & Dark greenish-gray \\
\hline 13/34RS & 73.70 & 51.10 & 2.52 & 5.50 & 4.00 & 16.17 & Greenish-black & Greenish-gray \\
\hline $14 / 25 \mathrm{RS}$ & 70.26 & 39.07 & 2.57 & 5.60 & 3.17 & 16.17 & Greenish-black & Dark greenish-gray \\
\hline $14 / 5 \mathrm{RS}$ & 72.40 & 41.80 & 2.55 & 5.00 & 3.33 & 14.50 & Greenish-black & Dark greenish-gray \\
\hline 14/17RS & 64.81 & 45.57 & 2.72 & 5.30 & 3.83 & 14.00 & Greenish-black & Greenish-gray \\
\hline 14/8RS & 71.28 & 66.50 & 2.75 & 5.75 & 4.00 & 15.00 & Greenish-black & Greenish-gray \\
\hline $14 / 26 \mathrm{RS}$ & 73.62 & 48.23 & 2.57 & 5.60 & 3.33 & 16.00 & Greenish-black & Greenish-gray \\
\hline 14/10RS & 69.15 & 41.63 & 2.57 & 6.00 & 2.83 & 12.50 & Greenish-black & Greenish-gray \\
\hline 14/9RS & 71.84 & 68.63 & 2.72 & 4.70 & 4.00 & 14.17 & Greenish-black & Greenish-gray \\
\hline 14/21RS & 74.38 & 30.50 & 2.67 & 4.10 & 3.17 & 16.50 & Greenish-black & Greenish-gray \\
\hline 15/7RS & 71.06 & 52.57 & 2.77 & 5.30 & 2.67 & 14.83 & Greenish-black & Greenish-gray \\
\hline $15 / 23 \mathrm{RS}$ & 67.39 & 63.33 & 2.60 & 4.45 & 4.17 & 13.33 & Greenish-black & Greenish-gray \\
\hline $15 / 5 \mathrm{RS}$ & 71.97 & 37.33 & 2.52 & 5.50 & 3.17 & 14.17 & Greenish-black & Greenish-gray \\
\hline 16/16RS & 75.06 & 7.28 & 2.62 & 5.20 & 3.33 & 14.83 & Greenish-black & Greenish-gray \\
\hline 16/13RS & 74.71 & 19.33 & 2.57 & 6.00 & 3.83 & 18.50 & Greenish-black & Dark greenish-gray \\
\hline 16/2RS & 74.69 & 2.22 & 2.90 & 5.35 & 4.33 & 16.00 & Greenish-black & Greenish-gray \\
\hline 16/17RS & 73.36 & 42.77 & 2.52 & 5.45 & 3.17 & 14.17 & Greenish-black & Greenish-gray \\
\hline 17/2RS & 73.58 & 60.93 & 2.52 & 5.20 & 3.83 & 13.33 & Greenish-black & Greenish-gray \\
\hline 17/18RS & 73.14 & 60.00 & 2.67 & 4.15 & 4.67 & 19.33 & Greenish-black & Greenish-gray \\
\hline
\end{tabular}

A phylogenetic dendrogram was constructed using an alignment of $T E F-1 \alpha$ sequences from the isolates obtained in this study and those of Cladosporium spp isolates in GenBank (Figure 3). The phylogenetic tree resulted from grouping genetically similar isolates, and corroborated certain aspects of the dendrogram generated with morphological data (Figure 2). Sequences from isolates 16/16RS, 7SC, 15/5RS, 14/5RS, 13/1RS, 11RS, 17/2RS, 16/17RS, 16/13RS, 14/25RS, 14/17RS, 13/34RS, 13/10RS, 10RS, 2/2PR, and 6SC were clustered in a clade with others from GenBank associated with C. pseudocladosporioides, indicating high genetic similarity between these organisms. In addition, 8RS and 13/12RS were also shown to be very similar to each other, being grouped in a separate clade including other GenBank $C$. pseudocladosporioides sequences.

Other isolates (12/1PR, 12/14PR, and 14/26RS) were found to share genetic similarity with a C. cladosporioides sequence deposited in GenBank under accession No. HM148292.1. Likewise, isolate 9RS grouped with HM148249.1, and 2/1PR with HM148248.1, accession Nos. for sequences identified as $C$. cladosporioides $T E F-1 \alpha$. Isolates 12/6PR, 15/23RS, 3PR, 


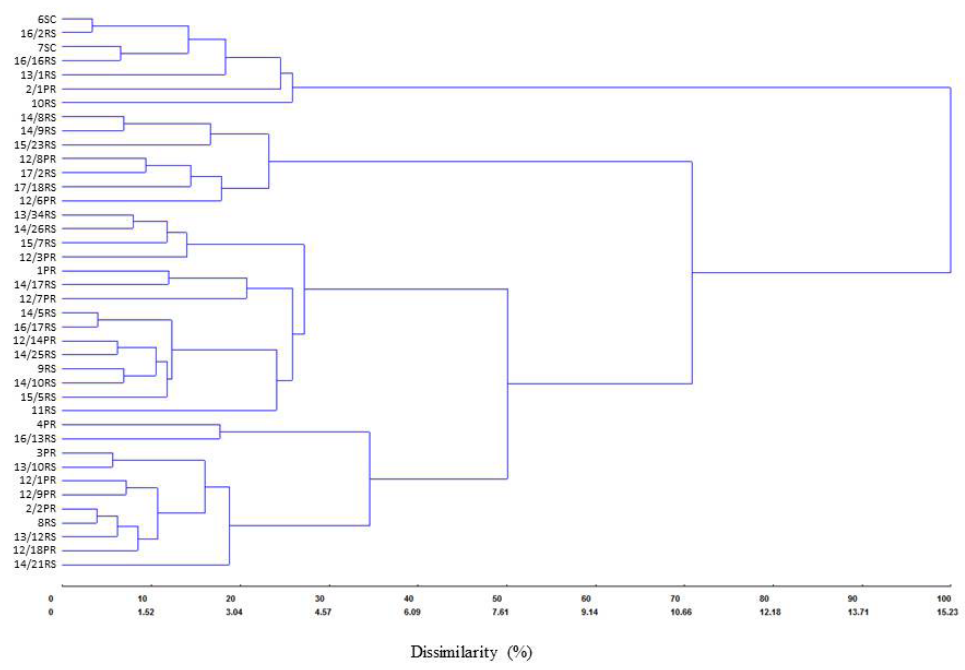

Figure 2. Dendrogram of estimated dissimilarity (percentages) among 40 Cladosporium spp isolates obtained from pecan trees (Carya illinoinensis). The dendrogram was generated using the unweighted pair group method with arithmetic mean based on a Euclidean distance matrix comprising six morphological characters (mycelial growth, sporulation, and width and length of conidia and ramoconidia).

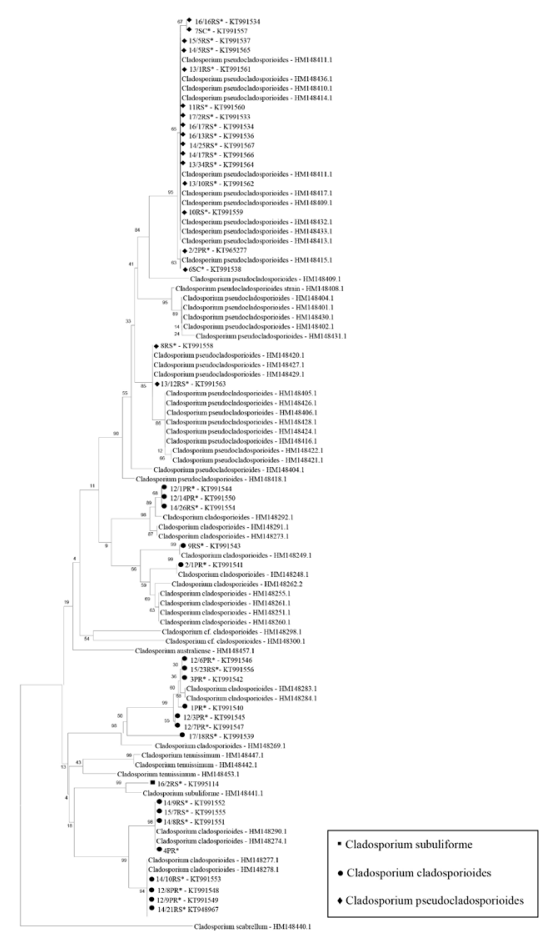

Figure 3. Phylogenetic dendrogram of TEF-1 $\alpha$ DNA sequences based on the neighbor-joining method with 1000 bootstrap replicates. Numbers on branches represent bootstrap support. *Cladosporium spp isolates obtained in this study.

Genetics and Molecular Research 15 (3): gmr.15038714 
1PR, 12/3PR, 12/7PR, and 17/18RS were incorporated in a larger group and subdivided, showing a high level of genetic similarity to each other. Sequences from 14/9RS, 15/7RS, 14/8RS, 4PR, 14/10RS, 12/8PR, 12/9PR, and 14/21RS were included in another big clade, divided into smaller groups, confirming a genetic affinity between some of the organisms isolated in this study and those described in GenBank as C. cladosporioides. Only isolate 16/2RS was affiliated in the phylogenetic dendrogram with C. subuliforme (HM148441.1).

Phylogenetic analysis was able to distinguish between the isolates, and confirmed that 20 of them shared a high degree of genetic similarity with GenBank sequences reported as C. cladosporioides, while 18 exhibited substantial genetic resemblance to C. pseudocladosporioides. Only one isolate showed greater sequence homology with $C$. subuliforme.

\section{DISCUSSION}

The Cladosporium spp morphological characteristics recorded in the present study were consistent with those reported in other investigations under similar conditions (culture medium, temperature). Our observations agree with those described previously for $C$. cladosporioides, C. pseudocladosporioides, and C. subuliforme, for which colony pigmentation was gray olivaceous on the surface, and on the reverse olivaceous black, or olivaceous gray in the latter species. The morphological attributes of these species are very similar, making it difficult to distinguish between them using only such characters. Moreover, C. cladosporioides has wider and longer secondary ramoconidia than $C$. pseudocladosporioides, yet these species are phylogenetically close (Bensch et al., 2010).

Lazarotto et al. (2014b) found colony diameter to be the morphological character that contributes most to differentiation between isolates of the genetically similar Pestalotiopsis spp group found in pecan trees. The results obtained here indicate that differences in sporulation were predominantly responsible for the characteristic grouping of isolates in

our dendrogram. However, morphological analysis must be compared with the outcome of molecular examination, as some characters are indistinguishable between species.

On its own, the morphological key used to identify species of the C. cladosporioides complex (Bensch et al., 2010) did not allow differentiation of the present isolates, thus it was necessary to compare this data with a molecular phylogeny. Current studies concerning the identification of fungal isolates seek to match morphological and molecular characteristics, thereby increasing the reliability of any conclusions reached. Lazarotto et al. (2014b), in an attempt to identify and characterize pathogenic Pestalotiopsis spp isolated from pecan trees, used morphological features (mycelial growth, sporulation, colony pigmentation, and conidia length and width), as well as sequences of the internal transcribed spacer (ITS) region and $\beta$-tubulin.

To establish the identity and taxonomy of fungi deposited in databases as $C$. cladosporioides, Bensch et al. (2010) re-examined these isolates from various substrates and geographic areas. They sequenced three genomic regions (ITS, actin, and TEF-1 $\alpha$ ) and supplemented this data with morphological analyses, in order to clarify the diversity of species included in the C. cladosporioides complex. This complex comprises species that are morphologically close to $C$. cladosporioides but distinguishable due to a subtle combination of features, in addition to some strains morphologically indistinguishable from this species but phylogenetically distinct as C. pseudocladosporioides.

Genetics and Molecular Research 15 (3): gmr.15038714 
Use of $T E F-1 \alpha$ sequences allowed the effective identification and grouping of the isolates in the present study. It should be noted that in a previous analysis of three Cladosporium isolates, the ITS region was not sufficient to identify the species under examination. Braun et al. (2003) indicated that assessment of ITS sequences alone does not permit the molecular delimitation of Cladosporium species. Schubert et al. (2007) carried out molecular and morphological analyses of the $C$. herbarum complex, demonstrating that a multilocus approach based on five regions (rDNA ITS, actin, calmodulin, $T E F-1 \alpha$, and histone H3) results in greatly improved resolution, appropriate for species-level identifications.

Understanding the genetic diversity of a pathogen population is critical to breeding program strategies for the production of resistant crops, as reported by Bock et al. (2014) for the selection of scab-resistant germplasm. Apple scab, caused by Venturia inaequalis, was best characterized using knowledge of the genetic diversity among populations of species of the Venturiaceae family. Thus, molecular studies have provided new insights into the epidemiology and possible treatment of this disease (Xu et al., 2013). In pecan trees, F. effusum has been shown to be genetically diverse across the southeastern United States, with little evidence to differentiate between populations (Chen et al., 2014). Similarly, in the present study, phylogenetic analysis was fundamental to verify similarity among isolates of Cladosporium spp causing pecan leaf spot, which will facilitate future pathogenicity studies.

Given these results, it is of note that this represents the first example of pecan leaf spot worldwide to be caused by species of the $C$. cladosporioides complex not involving $F$. effusum (syn. C. caryigenum). However, this study was limited by the relatively small number of sampling areas. The examination of other orchards in southern Brazil is needed to further test for the presence of $F$. effusum, the recognized causative agent of pecan scab, in natural conditions.

\section{Conflicts of interest}

The authors declare no conflict of interest.

\section{ACKNOWLEDGMENTS}

The authors thank Coordenação de Aperfeiçoamento de Pessoal de Nível Superior (CAPES) for granting a doctoral scholarship to the first author, and the CNPq for the PQ scholarship awarded to M.F.B. Muniz.

\section{REFERENCES}

Alfenas AC and Ferreira FA (2007). Inoculação de fungos fitopatogênicos. In: Métodos em fitopatologia (Alfenas AC and Mafia RG, eds.). Universidade Federal de Viçosa, Viçosa, 117-138.

Anilkumar TB and Seshadri VS (1975). Cladosporium leaf spot of sunflower. Curr. Sci. 44: 722.

Beck A, Ritschel A, Schubert K, Braun U, et al. (2005). Phylogenetic relationships of the anamorphic genus Fusicladium s. lat. as inferred by ITS nrDNA data. Mycol. Prog. 4: 111-116. http://dx.doi.org/10.1007/s11557-006-0114-8

Bensch K, Groenewald JZ, Dijksterhuis J, Starink-Willemse M, et al. (2010). Species and ecological diversity within the Cladosporium cladosporioides complex (Davidiellaceae, Capnodiales). Stud. Mycol. 67: 1-94. http://dx.doi. org/10.3114/sim.2010.67.01

Bensch K, Braun U, Groenewald JZ and Crous PW (2012). The genus Cladosporium. Stud. Mycol. 72: 1-401.

Berner DK, Smallwood EL, McMahon MB, Luster DG, et al. (2007). First report of leaf spot caused by Cladosporium

Genetics and Molecular Research 15 (3): gmr.15038714 
herbarum on Centaurea solstitialis in Greece. Plant Dis. 91: 463.

Bock CH, Wood BW, Stevenson KL and Arias RS (2014). Genetic diversity and population structure of Fusicladium effusum on pecan in the United States. Plant Dis. 98: 916-923. http://dx.doi.org/10.1094/PDIS-12-13-1229-RE

Braun U, Crous PW, Dugan F, Groenewald JZ, et al. (2003). Phylogeny and taxonomy of Cladosporium-like hyphomycetes, including Davidiella gen. nov., the teleomorph of Cladosporium s. str. Mycol. Prog. 2: 3-18. http:// dx.doi.org/10.1007/s11557-006-0039-2

Chen RS, Wang WL, Li JC, Wang YY, et al. (2009). First report of papaya scab caused by Cladosporium cladosporioides in Taiwan. Plant Dis. 93: 426. http://dx.doi.org/10.1094/PDIS-93-4-0426C

Chen C, Bock CH, Brannen PM, Adaskaveg JE, et al. (2014). Genetic variability among populations of Fusicladium species from different host trees and geographic locations in the USA. Mycol. Prog. 13: 1179-1190.

Cruz CD (2008). Programa GENES: diversidade genética. Universidade Federal de Viçosa, Viçosa.

de Souza JI, Pires-Zottarelli CL, Dos Santos JF, Costa JP, et al. (2012). Isomucor (Mucoromycotina): a new genus from a Cerrado reserve in state of São Paulo, Brazil. Mycologia 104: 232-241. http://dx.doi.org/10.3852/11-133

Doyle JJ and Doyle JL (1990). Isolation of plant DNA from fresh tissue. Focus 12: 13-15.

Fernandez MR (1993). Manual para laboratório de fitopatologia. Embrapa-CNPT, Passo Fundo.

Hall TA (1999). BioEdit: a user-friendly biological sequence alignment editor and analysis program for Windows 95/98/ NT. Nucleic Acids Symp. Ser. 41: 95-98.

Instituto Brasileiro de Geografia e Estatística (2015). Available at [http://www.ibge.gov.br/estadosat/temas.php?sigla=rs\& tema=lavourapermanente2013]. Accessed August 22, 2015.

Lazarotto M, Milanesi PM, Muniz MF, Reiniger LR, et al. (2014a). Morphological and molecular characterization of Fusarium spp pathogenic to pecan tree in Brazil. Genet. Mol. Res. 13: 9390-9402. http://dx.doi.org/10.4238/2014. November.11.5

Lazarotto M, Bovolini MP, Muniz MFB, Harakawa R, et al. (2014b). Identification and characterization of pathogenic Pestalotiopsis species to pecan tree in Brazil. Pesqui. Agropecu. Bras. 49: 440-448. http://dx.doi.org/10.1590/S0100204X2014000600005

Marchiori JNC (1997). Dendrologia das Angiospermas: das Magnoliáceas às Flacurtiáceas. Editora da Universidade Federal de Santa Maria, Santa Maria.

Ministério da Agricultura Pecuária e Abastecimento (2015). Available at [http://extranet.agricultura.gov.br/php/proton/ cultivarweb/cultivares_registradas.php]. Accessed August 22, 2015.

Oliveira RR, Aguiar RL, Tessmann DJ, Nunes WMC, et al. (2014). First report of leaf spot caused by Cladosporium perangustum on Syagrus oleracea in Brazil. Plant Dis. 98: 280. http://dx.doi.org/10.1094/PDIS-06-13-0595-PDN

Schubert K, Groenewald JZ, Braun U, Dijksterhuis J, et al. (2007). Biodiversity in the Cladosporium herbarum complex (Davidiellaceae, Capnodiales), with standardisation of methods for Cladosporium taxonomy and diagnostics. Stud. Mycol. 58: 105-156. http://dx.doi.org/10.3114/sim.2007.58.05

Shoukouhi P and Bissett J (2009). Preferred primers for sequencing the $5^{\prime}$ end of the translation elongation factor-1a gene (eEF1a1). ISTH. Available at [http://www.isth.info/methods]. Accessed June 23, 2015.

Tamura K, Dudley J, Nei M and Kumar S (2007). MEGA4: Molecular Evolutionary Genetics Analysis (MEGA) software version 4.0. Mol. Biol. Evol. 24: 1596-1599. http://dx.doi.org/10.1093/molbev/msm092

Thompson TE and Conner PJ (2012). Pecan. In: Fruit breeding, handbook of plant breeding (Badenes ML and Byrne DH, eds.). Springer, New York, 771-801.

Walker C, Muniz MFB, Martins RRO, Mezzomo R, et al. (2016). First report of species in the Cladosporium cladosporioides complex causing pecan leaf spot in Brazil. J. Plant Pathol. 98: 370.

Xu X, Harvey N, Roberts A and Barbara D (2013). Population variation of apple scab (Venturia inaequalis) within mixed orchards in the UK. Eur. J. Plant Pathol. 135: 97-104. http://dx.doi.org/10.1007/s10658-012-0068-4

Zheng C, Liu ZH, Tang SS, Lu D, et al. (2014). First report of leaf spot caused by Cladosporium oxysporum on greenhouse eggplant in China. Plant Dis. 98: 566. http://dx.doi.org/10.1094/PDIS-06-13-0606-PDN

Genetics and Molecular Research 15 (3): gmr.15038714 